\title{
Efisiensi Ekonomi Pemeliharaan Ayam Kampung Super yang Diberi Fitobiotik dengan Teknologi Nanoenkapsulasi Minyak Buah Merah (Pandanus conoideus)
}

\section{Economic Efficiency Maintenance of Super Native Chickens Provided by Phytobiotics with Nanoenacpsulation Technology of Red Fruit Oil (Pandanus conoideus)}

\author{
Maria Herawati, Syaefullah BL, Timur NPVT \\ Politeknik Pembangunan Pertanian Manokwari, Jl. SPMA Reremi Kotak Pos 143 Kelurahan \\ Manokwari Barat, Manokwari-Papua Barat 98312 \\ herawatimaria@yahoo.com
}

\begin{abstract}
Red fruid as one of Indonesia's native medicinal plants as a phytobiotic is developed to maintain the health status of livestock. The drawback of using phytobiotics as feed additives is done by making nanoencapsulation so that the products are easily absorbed by the livestock digestive system. This research was conducted to know the value of the economic efficiency using red fruit oil nanoencapsulation in super native chickens. The study used a descriptive method with 5 treatments and 4 replication. P0 (control), P1 (2.5\% red fruit oil extract), P2 (2.5\% red fruit oil nanoencapsulation), P3 (5\% red fruit oil nanoencapsulation), P4 (10\% red fruit oil nanoencapsulation). The result showed that the economic efficiency of using feed in each treatment was efficient $(E E P P<1)$ dan the best business efficiency $(R / C)$ in P2 treatment $(1,474)$. The conclusion of this study is that the use of red fruit oil nanoencapsulation in super native chicken can provide a better economic efficiency value than those without nanoencapsulation. The use of $2.5 \%$ red fruit oil nanoencapsulation gave the best economic efficiency value compared to other treatments.
\end{abstract}

Keywords: Red fruit, efficiency, economy, phytobiotics, nanoencapsulation

\section{PENDAHULUAN}

Ayam kampung super adalah salah satu produk hasil persilangan antara ayam kampung dengan ayam ras. Ayam kampung super banyak diminati untuk dibudidayakan oleh peternak karena memiliki kelebihan dibandingkan ayam kampung biasa, antara lain laju pertumbuhan yang cepat dan masa pemeliharaan yang singkat.

Upaya untuk meningkatkan status kesehatan ternak, memacu pertumbuhan (growth promotor) dan meningkatkan efisiensi pakan, pada umumnya industri peternakan menggunakan antibiotik. Kekurangan dari penggunaan antibiotik antara lain dapat meninggalkan residu pada produk peternakan sehingga alternatif lain dari antibiotika adalah dengan menggunakan hasil tanaman (fitobiotik). 
Salah satu fitobiotik yang dapat dimanfaatkan sebagai growth promotor alami adalah buah merah yang merupakan salah satu tanaman obat asli Indonesia, berasal dari Papua. Buah merah dikenal memiliki banyak manfaat untuk meningkatkan kekebalan tubuh dan mempertahankan status kesehatan manusia. Kekurangan dari penggunaan fitobiotik sebagai feed additive, yaitu memiliki daya kelarutan yang rendah, cepat terdegradasi, penyebarannya kurang merata, bioavailabilitasnya rendah, dan cepat rusak oleh pengaruh lingkungan dalam sistem pencernaan (Esfanjani dan Fajri, 2016). Usaha yang dilakukan untuk mengatasi kekurangan tersebut adalah dengan pembuatan nanoenkapsulasi. Ukuran partikelnya yang kecil membuat produknya mudah diserap oleh sistem pencernaan ternak. Penambahan nanoenkapsulasi minyak buah merah diharapkan dapat memaksimalkan kinerja usus dalam mencerna dan menyerap nutrisi. Berdasarkan hal tersebut, maka perlu dilakukan penelitian untuk melihat nilai efisiensi ekonomi pada pemeliharaan ternak ayam kampung super yang diberi fitobiotik dengan teknologi nanoenkapsulasi minyak buah merah.

\section{MATERI DAN METODE}

\section{Waktu dan Tempat}

Penelitian ini dilaksanakan pada bulan Maret-April 2020 bertempat di Kampus Politeknik Pembangunan Pertanian Manokwari, Papua Barat.

\section{Alat dan Bahan}

Alat yang digunakan dalam penelitian ini adalah kandang, timbangan digital, blender, gelas takar, sendok makan, botol penampung, thermometer-hygrometer, tirai plastik, ember, tempat pakan dan minum, pisau, kompor.

Bahan yang digunakan dalam penelitian ini adalah minyak buah merah, kitosan, Sodium Tripolyphospat (STPP), asam asetat, dan 100 ekor DOC ayam kampung super.

\section{Metode Penelitian}

Metode yang digunakan dalam penelitian ini adalah metode deskriptif dengan 5 perlakuan dan 4 ulangan. Setiap ulangan terdiri dari 5 ekor ayam kampung super yang diberikan perlakuan sebagai berikut:

$\mathrm{PO}=$ air minum tanpa aditif (kontrol negatif)

$\mathrm{P} 1=$ air minum $+2,5 \%$ ekstrak minyak buah merah

$\mathrm{P} 2$ = air minum $+2,5 \%$ nanoenkapsulasi minyak buah merah

P3 = air minum + $5 \%$ nanoenkapsulasi minyak buah merah

$\mathrm{P} 4=$ air minum $+10 \%$ nanoenkapsulasi minyak buah merah

\section{Pembuatan minyak buah merah dan proses nanoenkapsulasi}

Buah merah yang matang dipisahkan dari empelurnya kemudian dipotong-potong dan dicuci bersih. Daging buah dikukus di atas api sedang selama 1-2 jam, setelah itu dipisahkan dari biji dan ditambahkan air hingga ketinggian $5 \mathrm{~cm}$. Setelah itu diperoleh santan yang kemudian dimasak kembali dengan api sedang selama 5-6 jam, diaduk sampai muncul minyak berwarna kehitaman. Setelah didiamkan selama satu hari, 
akan berbentuk tiga lapisan, yaitu air di lapisan bawah, ampas di lapisan tengah dan minyak di lapisan atas.

Proses nanoenkapsulasi menggunakan metode gelasi ionik yaitu dengan mencampurkan $2 \%$ minyak buah merah (hasil ekstrak buah merah dengan $96 \%$ etanol): $0,625 \%$ kitosan (kitosan yang telah dilarutkan dalam 2,50\% asam asetat, diaduk dengan menggunakan blender selama 2 menit): 0,75\% STPP (yaitu $0,75 \%$ STPP yang telah dilarutkan dengan aquades dan diaduk menggunakan magnetic stirrer selama 30 menit). Perbandingan larutan nanoenkapsulasi sebagai fitobiotik yaitu ekstrak ampas buah merah, kitosan dan STPP $(0,50: 1,00: 0,02)$ (Sundari, dkk 2014).

\section{Analisis Data}

Efisiensi Ekonomi Penggunaan Pakan (EEPP)

Efisiensi ekonomi penggunaan pakan dinyatakan dengan rumus (Bana dkk, 2017).

$$
\text { EEPP }=\frac{\text { Biaya ransum }(\mathrm{Rp})}{\text { Nilai PBB }(\mathrm{Rp})}
$$

Kriteria Efisiensi :

a. EEPP $<1$ maka penggunaan pakan efisien

b. EEPP > 1 maka penggunaan pakan tidak efisien

Efisiensi usaha

Efisiensi usaha dihitung dengan menggunakan R/C Ratio yaitu perbandingan antara penerimaan dengan biaya (Sidabutar dkk, 2018).

Efisiensi $=\frac{\mathrm{TR}}{\mathrm{TC}}$

Dimana :

$\mathrm{TR}=$ Total penerimaan $(\mathrm{Rp})$

$\mathrm{TC}=$ Total biaya $(\mathrm{Rp})$

Kriteria efisiensi:

$\mathrm{R} / \mathrm{C}>1$ = usaha efisien

$\mathrm{R} / \mathrm{C}=1$ = usaha impas

$\mathrm{R} / \mathrm{C}<1$ = usaha tidak efisien

\section{HASIL PENELITIAN}

\section{Biaya dan Pendapatan}

Biaya total terdiri dari biaya tetap dan biaya variabel, biaya tetap terdiri dari komponen biaya penyusutan kandang, penyusutan peralatan, tenaga kerja dan listrik, untuk biaya variabel terdiri dari komponen biaya DOC, pakan, dan penggunaan fitobiotik (Tabel 1). Penggunaan biaya tetap untuk setiap perlakuan adalah sama yaitu sebesar Rp.58.000,-, sedangkan untuk biaya variabel untuk setiap perlakuan berturutturut sebesar Rp.559.536,73 (P0); Rp.1.811.099,05 (P1); Rp.735.702,6 (P2); Rp.808.176,69(P3) dan Rp.916.322,76 (P4). Total biaya yang digunakan dalam penelitian ini adalah berturut-turut yaitu Rp.617.536.73 (P0); Rp.1.869.099,05 (P1); 
Rp.793.702,6 (P2); Rp.866.176,69 (P3) dan Rp.974.322,76 (P4). Total biaya terbesar yang digunakan dalam penelitian ini adalah pada perlakuan P1, diikuti P4, P3 dan P2, sedangkan total biaya terendah pada perlakuan P0. Tingginya total biaya pada perlakuan disebabkan karena adanya penambahan fitobiotik pada perlakuan P2, P4, P3 dan P2. Penambahan fitobiotik juga meningkatkan nafsu makan sehingga biaya penggunaan pakan juga meningkat.

Tabel 1. Komponen biaya, pendapatan dan efisiensi ekonomi

\begin{tabular}{|c|c|c|c|c|c|}
\hline URAIAN & PO & P1 & P2 & P3 & P4 \\
\hline \multicolumn{6}{|l|}{ Biaya Tetap } \\
\hline Penyusutan kandang (Rp) & 20.000 & 20.000 & 20.000 & 20.000 & 20.000 \\
\hline Penyusutan alat (Rp) & 8.800 & 8.800 & 8.800 & 8.800 & 8.800 \\
\hline Tenaga kerja (Rp) & 10.000 & 10.000 & 10.000 & 10.000 & 10.000 \\
\hline Listrik & 20.000 & 20.000 & 20.000 & 20.000 & 20.000 \\
\hline Total Biaya Tetap (Rp) & 58.000 & 58.000 & 58.000 & 58.000 & 58.000 \\
\hline \multicolumn{6}{|l|}{ Biaya variabel } \\
\hline DOC (Rp) & 300.000 & 300.000 & 300.000 & 300.000 & 300.000 \\
\hline Pakan (Rp) & $259.536,73$ & $261.099,05$ & $343.677,60$ & $346.376,69$ & $291.722,76$ \\
\hline Fitobiotik (Rp) & 0 & 1.250 .000 & 92.025 & 161.800 & 323.600 \\
\hline Total Biaya Variabel (Rp) & $559.536,73$ & $1.811 .099,05$ & $735.702,6$ & $808.176,69$ & $916.322,76$ \\
\hline Total Biaya (Rp) & $617.536,73$ & $1.869 .099,05$ & $793.702,6$ & $866.176,69$ & $974.322,76$ \\
\hline \multicolumn{6}{|l|}{ Pendapatan } \\
\hline Ayam terjual (ekor) & 13 & 14 & 18 & 19 & 15 \\
\hline $\begin{array}{l}\text { Pendapatan Kotor (Rp) } \\
\text { Pendapatan Bersih (Rp) }\end{array}$ & $\begin{array}{r}910.000 \\
292.463,27\end{array}$ & $\begin{array}{r}840.000 \\
-1.029 .099,05\end{array}$ & $\begin{array}{l}1.170 .000 \\
376.297,4\end{array}$ & $\begin{array}{r}1.140 .000 \\
273.823,31\end{array}$ & $\begin{array}{r}975.000 \\
677,24\end{array}$ \\
\hline \multicolumn{6}{|l|}{ Efisiensi : } \\
\hline Rerata harga jual (Rp/kg) & 87.281 & 88.626 & 87.248 & 86.830 & 87.719 \\
\hline Rerata PBB (kg) & 0,755 & 0,587 & 0,808 & 0,677 & 0,720 \\
\hline Nilai PBB (Rp) & 65.889 & 52.023 & 70.496 & 58.783 & 63.158 \\
\hline EEPP & 0,30 & 0,36 & 0,27 & 0,31 & 0,31 \\
\hline $\mathrm{R} / \mathrm{C}$ & 1,473 & 0,449 & 1,474 & 1,316 & 1,000 \\
\hline
\end{tabular}

Pendapatan kotor dalam penelitian ini adalah hasil penjualan ternak ayam kampung super (Tabel 1). Besarnya pendapatan kotor setiap perlakuan berbeda yaitu Rp.910.000 (P0); Rp.840.000 (P1); Rp.1.170.000 (P2); Rp.1.140.000 (P3) dan Rp.975.000 (P4). Perbedaan jumlah pendapatan kotor yang diterima disebabkan oleh jumlah ayam terjual dan besarnya bobot badan ayam yang memengaruhi harga jual. Pendapatan kotor tertinggi pada perlakuan P2 kemudian diikuti P3, P4, P0 dan terendah pada perlakuan P1. Hal ini menunjukkan bahwa dengan adanya penambahan nanoenkapsulasi dapat meningkatkan hasil penjualan ternak atau meningkatkan pendapatan kotor.

Pendapatan bersih adalah selisih antara pendapatan kotor dengan biaya total. Pendapatan bersih tertinggi yang diperoleh pada perlakuan P2, diikuti P0, P3, dan P4, 
sedangkan pada perlakuan P1 mengalami kerugian yang disebabkan oleh biaya penambahan fitobiotik dan jumlah kematian ternak yang tinggi.

\section{Efisiensi}

Efisiensi ekonomi penggunaan pakan (EEPP) yang ditunjukkan pada Tabel 1 terlihat bahwa EEPP pada perlakuan P0 $(0,30)$, P1 $(0,36)$, P2 $(0,27)$, P3 $(0,31)$ dan P4 $(0,31)$. Nilai EEPP pada setiap perlakuan lebih kecil dari $1(E E P P<1)$ artinya penggunaan pakan setiap perlakuan efisien karena nilai pertambahan bobot badan yang diukur dalam rupiah lebih besar dibandingkan biaya ransumnya. Nilai EEPP semakin kecil akan semakin efisien, sehingga dapat diketahui bahwa nilai efisiensi penggunaan pakan terbaik yaitu pada perlakuan $\mathrm{P} 2$.

Efisiensi usaha dari penggunaan fitobiotik dari minyak buah merah pada ayam kampung super yang diperlihatkan pada nilai $\mathrm{R} / \mathrm{C}$ pada perlakuan P0 $(1,473)$, P1 $(0,449)$, P2 $(1,474)$, P3 $(1,316)$ dan P4 $(1,000)$. Nilai R/C memperlihatkan bahwa perlakuan $\mathrm{P} 0, \mathrm{P} 2$, dan $\mathrm{P} 3$ lebih besar dari $1(\mathrm{R} / \mathrm{C}>1)$, artinya usaha efisien dan layak dikembangkan, namun pada perlakuan $\mathrm{P} 1$ nilai $\mathrm{R} / \mathrm{C}$ lebih kecil dari $1(\mathrm{R} / \mathrm{C}<1)$ artinya usaha tidak efisien dan tidak layak untuk dikembangkan. Perlakuan P4 memperlihatkan bahwa nilai $\mathrm{R} / \mathrm{C}$ sama dengan $1(\mathrm{R} / \mathrm{C}=1)$ artinya usaha impas. Nilai $\mathrm{R} / \mathrm{C}$ yang semakin besar menunjukkan usaha semakin efisien, sehingga efisiensi usaha yang terbaik pada perlakuan P2 $(1,474)$.

\section{KESIMPULAN}

Penggunaan nanoenkapsulasi minyak buah merah pada ayam kampung super dapat memberikan nilai efisiensi ekonomi lebih baik dibandingkan yang tidak menggunakan nanoenkapsulasi. Penggunaan 2,5\% nanoenkapsulasi minyak buah merah memberikan nilai efisiensi ekonomi paling baik dibandingkan perlakuan lainnya.

\section{UCAPAN TERIMA KASIH}

Kami mengucapkan terimakasih kepada mahasiswa bimbingan M. T. H. Silitonga, I. Melindah, S. Anjarwati, O. S. Hardiyanti, A. H. Maswatu dan J. H. Andira yang telah membantu dalam penelitian.

\section{DAFTAR PUSTAKA}

Esfanjani, A.F. and S.M. Jafri. 2016. Biopolymer Nano-particles and Natural Nanocarriers for Nano-encapsulation of Phenolic Compounds. Colloids and Surfaces B: Biointerfaces. 146: 532-543.

Sundari, Zuprizal, and R. Martien. 2014. The Effect Nanocapsule of Turmeric

Extracts in Rations on Nutrient Digestibility of Broiler Chickens. Animal

Production. 16: 107-113. 
Bana, T., Lay, W., \& Niron, S. 2018. Nilai Ekonomi Penggunaan Pollard Dalam Ransum Komersial Babi Peranakan Landrace Fase Pertumbuhan. Jurnal Nukleus Peternakan, 5(2) 99-107.

https://ejurnal.undana.ac.id/nukleus/article/view/842.

Sidabutar, E. W., E. Tety dan S. Tarumun. 2018. Analisis Pendapatan Agroindustri Tahu Sumedang "Studi Kasus Agroindustri Tahu Sumedang Bapak Osmandri" di Desa Tanah Merah Kecamatan Siak Kabupaten Kampar. Pekbis Jurnal, 10(2) 147-157. https://pekbis.ejournal.unri.ac.id/index.php/JPEB/article/view/5803 